\title{
When Crop Producers Face Dynamic Climate Risks: Application of Multinomial Logit Model To Explain Adaptation Process
}

Sisay Belay Bedeke ( $\sim$ belaysisay@gmail.com )

Wolaita Sodo University

Research

Keywords: Adaptation choices, climate information, crop yield, resilience, seasonal rainfall, Africa

Posted Date: October 5th, 2021

DOl: https://doi.org/10.21203/rs.3.rs-919298/v1

License: (c) (i) This work is licensed under a Creative Commons Attribution 4.0 International License.

Read Full License 


\section{Abstract}

Background: Climate change is one of the major environmental challenge particularly affecting crop producers who depend on climate sensitive rainfed system. The contextual nature of farmers' adaptation and coping strategies to climate change continues to arouse the interest of several researchers. This study contributed to this growing area of research by examining factors and processes explaining the choice of crop producers' adaptation to dynamic climate change risks.

Method and material: Data were collected through household survey and interview. Multistage sampling was employed for selecting 340 household heads for interview. Descriptive statistics and multinomial logistic models were employed to analysis data collected.

Result and discussion: Results indicate that despite perceived increase in current and future climate change risks, farmers are testing and implementing a range of strategies by adjusting sowing date, using late or early maturing varieties, diversifying crop production using legumes and migrating to nearby cities in search of additional jobs as an income source during dry seasons. Contexts-specific factors significantly influencing the choice of adaptation strategies include gender of the household, access to extension services, level of awareness and perceptions, timely access to climate and weather information and size of landholding per household.

Conclusion: Based on the results of the study, it was concluded that the choice of adaptation to climate change is driven by much detailed socio-economic and institutional factors in addition to dynamic climatic factors. The study recommended that continuous financial, policy and technical support in terms of research, extension, innovation and awareness creation on improving behavioural and socio-economic aspects that influence adaptation choice should be provided.

\section{Introduction}

Scientific evidence indicates that the earth's climate is rapidly changing, owing to increases in greenhouse gas emissions (Khan \& Akhtar 2015). The increased concentration of greenhouse gases has raised the average temperature and altered the amount and distribution of rainfall globally. Such climate change risks are posing large impacts on agriculture which is the basis for Sub-Saharan African (SSA) economy (IPCC 2007; Kotir 2011; Falco 2014). Projected climate change is expected to have significant effects particularly on a rainfed crop producers (Falco 2014; Fisher et al. 2015).

Climate change may lead to a significant shift in time and location of cereal cropping and hence adversely affect productivity and yield (Cairns et al. 2013). For example, extreme heat stress may limit crop yield potential by accelerating growth and reducing the time of grain development. This can in turn influence farmers' cropping decision regarding when and where to plant. A study in the semi-arid areas of SSA shows that during its germination and growth stages cereal crops are more sensitive to heat stress than other cereal crops of temperate zone (Shi and Tao 2014). This suggests that rises in temperature could result in low cereal crop production and yields. Such risks in combination with erratic rainfall are 
likely to create favourable condition for the reproduction and spread of new crop pests and diseases (Tongruksawattana 2014). In addition, projected declines in crop yield due to droughts are more substantial (Abate et al. 2015). In Ethiopia, around $60 \%$ of the rainfed crop growing regions will face frequent droughts that could result in 10-25\% yield losses by 2030 (Fisher et al. 2015). To deal with climate change and underlying impacts, developing successful strategies that build farmers' resilience have become a top priority (Grothmann and Patt 2005; Khan and Akhtar 2015).

While mitigation is an important policy to deal with agricultural emissions (Cutter et al. 2009), adaptation is a key strategy to reduce climate change vulnerability (Niang et al. 2014). Farmers in Ethiopia are developing and testing several strategies to adapt to climate change (Hisali et al. 2011; Kassie et al. 2013; Falco 2014). For example, farmers in dryland areas may adapt to frequent droughts by choosing droughtresistant and short-maturing crop varieties as well as modulating planting dates (Deressa et al. 2009; Descheemaeker et al. 2016). In Malawi, Simelton et al. (2013) showed that farmers delay seed sowing periods for three weeks to avoid early season dry spells that lead to soil moisture loss. Moreover, farmers may implement rainwater harvesting practices, mixed planting of trees with crops and soil moisture conservation practices to increase productivity while reducing harmful climate change effects (Reed et al. 2013; Vignola et al. 2015). Such adaptation strategies may vary with respect to climate change risks (Smit and Wandel 2006; Antwi-Agyei et al. 2016). Strategies might also differ depending on location and the economic, political and institutional circumstances in which climate change stimuli are experienced and management decisions are made (Mimura et al. 2014; Shiferaw et al. 2014; Pereira 2017).

At the local level, adaptation analysis aimed at reducing vulnerability should take on the views of households and communities affected by climate change (Cutter et al. 2009; Crane et al. 2011). Adaptation is a complex process which demands that farmers assign scarce livelihood resources, strategies and capacities to deal with the perceived threat (Smit and Wandel 2006; Antwi-Agyei et al. 2016). Understanding the existing adaptive resources, strategies and capacities in turn may provide detailed information on how climate change risks occur as well as how farmers undertake decisions to deal with such risks (Grothmann and Patt 2005), which subsequently inform sustainable adaptation and development polices (Grothmann and Patt 2005). Although there are several studies that assess processes of adaptation processes in SSA and Ethiopia (Mertz et al. 2009; Alam et al. 2017; Elum et al. 2017), there are only a few empirical works that specifically examine the drivers and determinants of adaptation choices (Simelton et al. 2013; Abegunde 2017; Zewelde 2018). With this in mind, there is need for an in-depth study to explore how farmers find evidence of climate change and how their adaptation choices are influenced multiple drivers and determinants in SSA and Ethiopia. This would in turn help to develop more resilient policies that reduce risks associated with climate change (Shiferaw et al. 2014; Pereira 2017).

Promoting climate change adaptation in small farm settings can increase farm net revenues and ensure household food security by increasing productivity (Neufeldt et al. 2013) and reduce farmers' vulnerability (Descheemaeker et al. 2016). In particular, combining high-yield crop varieties together with tree planting for fodder and crop shade may help farmers maintain soil organic matter and moisture content as well as 
increase yields by reducing effects of extreme heat and soil degradation (Wainaina et al. 2016). However, most studies on climate change in SSA have investigated the drivers and barriers of specific climate change copping strategies such as consumption switching, livestock selling and early planting (Thornton and Herrero 2014). While the use of a single adaptation strategy is useful when one wants to deal with a specific production risk, this strategy alone may not be sufficient to address more serious risks associated with future climate change. There is a need to examine factors and processes influencing the choices of crop type and varietal selection, change in farming practices and diversification of livelihood that simultaneously offer economic and environmental benefits (Wainaina et al. 2016). Such analysis would provide useful information for developing successful and sustainable agricultural policies (Fisher et al. 2015).

In this study and to complement efforts made so far, we examine how several socio-economic, cognitive, institutional and behavioral factors explain crop producers' adaptation choices in Ethiopia.

\section{Theoretical Framework}

Climate change adaptation response can be related to the behavior of a particular farmer towards his environment. Human behavior, by its very nature, is notoriously complex and is multifaceted (Khan \& Akhtar 2015). In the context of adaptation to environmental changes, several theories have been applied to explain the adoption of one adaptation strategy over the other. From the wealth of several theories attempting to explain the drivers of adaptation behavior, we selected two that are most relevant to particular adaptation context (Li et al. 2017). These include the Protection Motivation Theory (PMT) and the Theory of Planned Behaviour (TPB).

\subsection{Protection motivation theory}

Propounded by Rogers in 1975, this theory was originally proposed to understand fear appeals and its coping strategies (Rogers 1975). However, in 1983 the theory was expanded to explain the concept of persuasive communication how people behave to cope with stressful conditions (Rogers et al. 1983). In the context of adaptation, the core assumption of the protection motivation theory is that people will normally protect themselves in two main perspectives: perceived self-efficacy in managing risks; and finally perceived efficacy of recommended preventive measures (Rogers et al. 2019). This theory aptly fits into explanations around how people respond to climate change threats and coping strategies against climate risks.

Self-efficacy is the belief in one's ability to cope with threatening climatic events and successfully execute recommended adaptation options (Khan \& Akhtar 2015). This implies that it is more likely that an individual will positively respond to or adopt coping strategies if he believes that he has the capacity and resources to execute such a coping strategy. This relates directly with the perceived resilience level of individuals against climatic threats. It also implies that costly coping strategies are less likely to be adopted by individuals. Another factor that will influence adoption of a coping strategy is the individual's 
expectancy and belief in the effectiveness of a recommended coping strategy to remove a climatic threat. Therefore, the PMT is one model that could be adopted to explain why individuals accept or reject some coping/adaptation strategies (Kassie et al. 2015). It goes further to suggest ways through which negative response/behavior towards climate change adaptation could be changed. One of such ways is the role of education and motivation in changing farmers' attitude towards climate change adaptation (Conway and Schipper 2011).

\subsection{Theory of planned behavior}

The Theory of Planned Behavior (TPB) proposed by Icek Ajzen is postulates that an individual's behavior is usually influenced not only by his pre-existing attitudes, but also by the expected potential outcome of his behavior (Rogers 1983). In addition to attitudes and expected behavioral outcomes, the TPB incorporates perceived behavioral control (rational thinking) as factors that govern individual's considerations, which in turn influence their choices, decisions, behavioral intentions, and behavior. The core assumption of the theory is that individual's personal attitude, subjective norms, and perceived behavioral control all come together to shape an individual's intentions and final behavior (Rogers 1983; Rogers et al. 2019).

According to the TPB, individual's attitudes will usually be influenced by cognitive beliefs which in turn affect one's intention to act or not to act. Where the outcomes of such intentions are favorably perceived, such intensions will most likely lead to positive behavior and increased likelihood of actual performance. This suggests that in a situation where the general society demonstrates a favorable response towards an issue, individuals are most likely to key it to the societal thinking and consequently develop a similar positive behavior towards such an issue. This could further explain the upsurge of positive interests about climate change adaptation in the society today. Many people are gradually becoming interested in climate change adaptation as a result of public awareness campaign and global interest on the matter (Baudoin 2014; Smit and Skinner 2002; Khan \& Akhtar 2015). The third distinguishing component of the TPB is the perceived behavioral control which influences one's intentions and behavior. This has to do with one's perceived ability to actually perform or engage in a particular behavior. Available literature on TPB shows that this perception is divided into internal and external.

\section{Methods}

\subsection{Study site}

Our study focused on cereal crop producers' adaptation choices to climate change, with a special emphasis on maize and haricot bean producers in two districts (i.e. Abala Abaya and Humbo, see figure 1) of Wolaita Zone, Ethiopia, which is highly dependent on rainfed agriculture and so that adversely affected by climate change. Both study districts are located at an elevation range of 800-1600 m above sea level (a. s. I.). They are predominantly characterized by semi-dry to sub-humid agro-ecological zones (AGRA 2014). Each agro-ecological zone reflects distinct micro-climatic and socio-economic patterns. Mean annual minimum and maximum temperatures are 18 and $34^{\circ} \mathrm{C}$, respectively, whereas average 
annual rainfall is $700 \mathrm{~mm}$ (WZANRD 2015). Maize is the most dominant staple crop in terms of production, occupying $42 \%$ of the land covered by grain crops (Abate et al. 2015) and providing $60 \%$ of dietary calories to rural consumers (CSA 2016). Soils are mainly reddish brown Eutric nitisolos on the steep slopes and reddish black Humic nitisols in the flat areas, with rainfed and irrigation systems (WZANRD 2015). Such farming systems believed to produce diversified information on climate change adaptation strategies.

\subsection{Sampling techniques}

In this study, a multi-stage sampling procedure (CSA 2016) was employed to select survey respondents for analyzing climate change adaptation choices. Accordingly, first, two districts that cover diverse topographic and socio-economic conditions were selected. Then, two villages that exhibit sameness in terms of microclimate, land use and livelihood systems were randomly selected from each district (totally four villages). Finally, a probability proportional to size sampling technique (CSA 2016), was employed for selecting 340 household heads from the study area. Household surveys were conducted from October to December 2019 through structured questionnaires, administered by trained enumerators who speak the local language and operate as a farm level agricultural extension agent. Questionnaires informed about adaptation household socio-economic, behavioral, cognitive and institutional conditions explaining adaptation choices. Data were subjected to statistical software, satat (version 11.0) for analysis.

\section{Analytical Framework \\ 4.1. Choice of model}

For a farmer to make choice on whether or not to adapt to a particular technology or innovation, he does not only consider how to maximize profit from that innovation but on how to attain the highest level of utility otherwise referred to as utility maximization (Grabowski et al. 2019). It is observed that farmers have a level of utility they want to meet and therefore make choices based on that. Any adaptation option could fall under the general framework of utility and profit maximization (Kassie et al. 2008). The utility of a farmer is given as $\mathrm{Uij}$, from choosing alternative $j$. Farmers will choose whether or not to adapt to climate change depending on the relative utility levels associated with the two choices. In this case, choice models are used to analyze a farmer's decision to adapt or not to adapt to climate change. This model assumes that farmers are likely to adopt a novel strategy only when an economic benefit obtained from such a strategy is significantly greater than from their actual strategy (Khan \& Akhtar 2015). Although farmers' profit maximizing behaviour using adaptation strategy is unobservable directly, their actions can be understood indirectly through choices they make (Bedeke et al. 2019).

This study employed a Multinomial Logit (MNL) model. This model is advantageous over other Multinomial Probit (MNP) model in that it allows predicting adaptation choice in terms of odds ratio with probabilities. The MNL is widely employed in climate change adaptation studies (Hisali et al. 2011; Tessema et al. 2013; Gbetibouo 2009; Gebrehiwot and Van Der Veen 2013). The MNL technique 
compares any given outcome with a reference outcome. This technique is deemed suitable to study adaptation to climate change since households employ different adaptation strategies which are typically not mutually exclusive. It is employed when the dependent variable has more than two outcomes or, in our case, more than one adaptation response to climate change (Greene 2012). To describe the MNL model, let $y$ denote a random variable taking on the values $\{0,1, \ldots ., M\}$ where $M$ is a positive integer and $x$ denote a set of conditioning variables. In our study, y would be adaptation measures taken by households whereas $\mathrm{x}$ represents the explanatory variables hypothesized to influence the choice of the available adaptation options. The MNL model is employed to show how ceteris paribus changes in the elements of $x$ influence the response probabilities, $P(y=m / x), m=0,1, \ldots, M . P(y=m / x)$ is known after determining the probabilities for $m=0,1,2, \ldots, M$, which must sum to unity. The MNL model has response probabilities given as Equation (1):

$$
p(y=m 1 x)=\frac{\exp (x \beta m)}{1+\sum_{i \neq m} \exp (x \beta m)} \mathrm{m}=1, \ldots, \mathrm{M}
$$

The parameter estimates of the MNL model only show the direction of the relationship between the dependent and independent variables. Therefore, to determine the actual magnitude of change or probabilities, the marginal effect of the explanatory variables, Equation 1 is differentiated over the explanatory variables to give Equation (2):

$$
\frac{\partial p(p=m / x)}{\partial x k}=p(y=m / x)\left[\beta_{n \dot{k}}-\frac{\sum_{n \geq 1} \beta_{n k} \exp (x \beta n)}{1+\sum_{n \geq 1} \exp (x \beta n)}\right]
$$

The MNL, however, works under the assumption of the Independent Irrelevant Alternatives (IIA). Following this assumption, the odds of any two outcomes are independent of the remaining outcomes available. Hence, omitting or adding outcomes should not affect the odds of the remaining outcomes (Hisali et al. 2011). The fitted MNL model was first checked to make sure that it does not violate this assumption.

\subsection{Model variables}

The fact that climate has changed in the past and will continue to change in the future underlies the need to understand adaptation processes, including its determinants and drivers (Hisali et al. 2011). Assessing farmers' climate change adaptation choice is important as several climate studies ask individuals about their choice to new practices that build resilience. Farmers' adaptation choices are driven by diverse institutional, socio-economic, behavioural and factors (Grothmann and Patt 2005; Woods et al. 2017).

\section{Dependent variable}

The dependent variable in this study is whether a household has 'adapted' or 'not adapted' any adaptation practices to climate change. Based on discussions with development staff, review of the 
literature and field observations, the adaptation practices identified included improved crop varieties (drought-tolerant and early maturing crops), crop diversification (mixed cropping and crop rotation), farm diversification (mulching, composting, ridging and terracing), change in planting date, income generating activities, irrigation practice (dry season gardening) and agroforestry. Adaptation choice is the dependent dummy variable. To determine the dummy, a value of ' 1 ' was assigned to those households that had adopted at least one of the adaptation options and ' 0 ' for those that had not adopted.

\section{Explanatory variables}

Explanatory variables hypothesized to influence the choice of adaptation strategies by crop producers are provided in detail.

\section{Institutional factors}

Institutional factors can include household access to weather information, agricultural input price information and access to agricultural training service. These factors have been widely used as variables in several adoption studies in order to evaluate farmers' behaviour (Bryan et al. 2009; Deressa et al. 2009; Mudzonga 2012). Farmers' access to information on weather change may have a significant relationship with their choice of climate change adaptation strategies (Nguezet et al. 2013). Exposure to extension services and mass media increase the awareness and concern regarding climate change. Such information obtained through extension agents or mass media (radio or television) can help promote crop and varietal choices (Grabowski et al. 2019). Access to detailed information on local market prices of improved crop varieties and pesticides is hypothesized to influence farmers' livelihood diversification choice (Nhemachena et al. 2014). This is because access to adequate market prices of agricultural inputs may be associated with their capability to undertake decisions to diversify into non-farm income strategies (Mulenga et al. 2016). Access to agricultural training services is found to influence farmers' adaptation decisions by enhancing their capacity to acquire new experience in dealing with climate change (Piya et al. 2013). Access to microcredit services may ease farmers' cash constraints and thus positively associated with choice of adaptation strategies such as chemical fertilizers, high-yielding crop varieties, and/or irrigation pumps (Nhemachena et al., 2014; Wainaina et al., 2016).

\section{Socio-economic factors}

Several studies used socio-economic factors such as education levels, farm experiences, land size and gender to explain household adaptation choices (Asfaw et al. 2013; Shiferaw et al. 2014; Boansi et al. 2017). A household education level is associated with access to output market price information as well as increased income that influence farmers' adaptation choices. Most climate change studies tend to agree that educated households are more able to process agricultural inputs, allocate them efficient, assess the profitability of the new strategy by taking into account costs and subsequently undertake decisions to adopt adaptation than illiterate households (Nguezet et al. 2013; Grabowski et al. 2019). With reference to the farm experience which is mainly related to age, several studies are of the view that households with high levels of farm experience are likely to undertake adaptation decisions (Bryan et al. 
2009; Deressa et al. 2009; Falco 2014). Large land size may enable households to undertake a variety of agricultural activities and hence is likely to affect farmers' adaptation decision (Kassie et al. 2013). Gender of the household may influence potential adoption of adaptation strategies to climate change (Ndiritu et al. 2014). Household non-farm income can be positively correlated with climate change adaptation choices. Increased household non-farm income from petty trading, woodworking and animal bartering provides farmers with additional financial capital for investing in improved crop varieties and fertilizers (M. Kassie, Teklewold, and Jaleta 2015). However, depending on household socio-economic and demographic contexts, climate change studies that examine the effect of gender differ on whether female or male household heads are more likely to adopt adaptation strategies (Asfaw et al. 2013; Falco 2014).

\section{Behavioural factors}

Several studies underscore the importance of farmers' behavioural factors such as risk perception in explaining adaptation choices (Adimassu et al. 2014; Niles and Mueller 2016; Sutcliffe et al. 2016). Farmers who perceived climate change risks in terms of increased temperatures are more likely to believe negative atmospheric warming that influence their choice to use heat and disease tolerant crop varieties (Niles and Brown 2016). Perceptions of declined annual rainfall risk is hypothesized to have a positive and significant relationship with choice of climate change adaptation strategies (Mertz et al. 2009). More frequent droughts and lack of sufficient rainfall risks driven by climate change are expected to adversely affect farmers' productivity and yields, and could subsequently influence their choice of adaptation (Kotir 2011; Shiferaw et al. 2014). Farmers' perceptions of increased seasonal rainfall variability patterns may have positive relationship with their choice of adaptation to climate change (Nguezet et al. 2013; Grabowski et al. 2019). Farmers who concerned with more increase in overall negative climate effects on their crop yields are likely to undertake adaptation choices (Niles and Brown 2016).

\section{Socio-cognitive factors}

The social-cognition approach assesses several forms of people's knowledge about global climate change that they have acquired through their long-term experience. Local people's beliefs in terms of climate change influence their adaptation choices in their farming and livelihood practices. These beliefs can be explained by local people's awareness of whether climate change is occurring and caused by human actions and/or natural events (Hyland et al. 2015). In northern Ethiopia, Tesfahunegn et al. (2016) showed that farmers' tree planting decisions in highly degraded lands may be influenced by their beliefs that climate change is caused by deforestation. As postulated by the theory of social-cognition that deals about human agency (Bandura 2001), local people's beliefs in climate change form the basis for critical information that bring changes in their attitudes following perturbation, and ultimately leads to explain adaptation choices.

However, increased climate uncertainty may lead to either absolute belief in or total denial of climate change (Abegunde 2017). Farmers can be either "believers" who have knowledge about its causes and occurrences or "disbelievers" who deny its existence. There are also some farmers who may choose to be 
neutral in their position towards climate change occurrence (Helgeson et al. 2012). Abegunde (2017) identified three sets of disbelievers in climate change cause, occurrence and effect: trend, attribution and impact sceptics. Trend sceptics are those people who never believe in climate change occurrence. Attribution sceptics accept the occurrence of climate change, but do not believe that this change is caused by a human action. Impact sceptics believe in climate change cause and its occurrence but deny its damage. For example, households may believe in the cause and occurrence of climate change, but they may find evidence of its impacts occurring elsewhere (Grothmann and Patt 2005). To this end, in this study, farmers' beliefs in climate change occurrence and risks is hypothesized to affect adaptation choices both positively and significantly (Helgeson et al. 2012). 
Table 1

Mean and standard deviations of dependent and explanatory variables used in the multinomial logistic model $(n=340)$.

\begin{tabular}{|c|c|c|c|}
\hline Variable name & Variable description & Mean & SD \\
\hline Access to climate information & $\begin{array}{l}=1 \text { if a farmer has access to climate } \\
\text { information, } 0 \text { otherwise }\end{array}$ & 0.58 & 0.37 \\
\hline Access to input price information & $\begin{array}{l}=1 \text { if a farmer has input price information, } 0 \\
\text { otherwise }\end{array}$ & 0.72 & 0.52 \\
\hline Access to micro credits & $\begin{array}{l}=1 \text { if a farmer has microcredit access, } 0 \\
\text { otherwise }\end{array}$ & 0.89 & 0.59 \\
\hline Access to training on adaptation & $\begin{array}{l}=1 \text { if a farmer receives training on agriculture, } \\
0 \text { otherwise }\end{array}$ & 0.48 & 0.36 \\
\hline Belief on climate change & $\begin{array}{l}=1 \text { if a farmer concern over climate change, } 0 \\
\text { otherwise }\end{array}$ & 0.73 & 0.45 \\
\hline Crop and varietal selection & $\begin{array}{l}=1 \text { if a farmer changed crop and variety use, } \\
0 \text { otherwise }\end{array}$ & 0.82 & 0.53 \\
\hline Education level (in years) & Number of years of schooling & 2.30 & 1.38 \\
\hline Farm experience (in years) & Number of years of experience in farming & 35.0 & 2.82 \\
\hline $\begin{array}{l}\text { Farmers' perception of increased } \\
\text { drought risks }\end{array}$ & $\begin{array}{l}=1 \text { if a farmer perceives increased drought } \\
\text { risks, } 0 \text { otherwise }\end{array}$ & 0.84 & 0.29 \\
\hline \multirow[t]{2}{*}{$\begin{array}{l}\text { Farmers' perception of increased } \\
\text { rainfall intensity }\end{array}$} & $\begin{array}{l}=1 \text { if a farmers perceives increased rainfall } \\
\text { intensity, } 0\end{array}$ & 0.58 & 0.39 \\
\hline & otherwise & & \\
\hline $\begin{array}{l}\text { Farmers' perceptions of increased } \\
\text { erratic rainfall }\end{array}$ & $\begin{array}{l}=1 \text { if a farmer perceives increased erratic } \\
\text { rainfall, } 0 \text { otherwise }\end{array}$ & 0.83 & 0.40 \\
\hline Gender of the household head & $\begin{array}{l}=1 \text { if a household is male-headed, } 0 \\
\text { otherwise }\end{array}$ & 0.79 & 0.68 \\
\hline Access to extension contact & $\begin{array}{l}=1 \text { if a farmer is visited by extension per } \\
\text { week, } 0 \text {, otherwise }\end{array}$ & 0.67 & 0.23 \\
\hline Household non-farm income & Average household non-farm income & 3234 & 234 \\
\hline Household on-farm income & Average on-farm income & 9420 & 340 \\
\hline Livelihood diversification & $\begin{array}{l}=1 \text { if a farmer diversify livelihood options, } 0 \\
\text { otherwise }\end{array}$ & 0.87 & 0.45 \\
\hline
\end{tabular}

Note that data were obtained from household survey 2018 to calculate the overall mean and Standard Deviation (SD) for the dependent and explanatory variables. Some explanatory variables were made dummy ( $1=y e s, 0=$ otherwise) for the sake of easier comparison in the MNL model though they are asked in terms of three-point scale. 


\begin{tabular}{|llll|}
\hline Variable name & Variable description & Mean & SD \\
\hline Shift farming practice & $\begin{array}{l}\text { =1 if a farmer shift farming practice, } 0 \\
\text { otherwise }\end{array}$ & 0.78 & 0.39 \\
\hline Size of farm (ha) & Average land size & 0.42 & 0.23 \\
\hline $\begin{array}{l}\text { Note that data were obtained from household survey 2018 to calculate the overall mean and Standard } \\
\text { Deviation (SD) for the dependent and explanatory variables. Some explanatory variables were made } \\
\text { dummy (1=yes, } 0=0 \text { otherwise) for the sake of easier comparison in the MNL model though they are } \\
\text { asked in terms of three-point scale. }\end{array}$ & \\
\hline
\end{tabular}

\section{Results And Discussion}

\subsection{Descriptive statistics on farmers' characteristics}

Of the total (340) household heads surveyed, most farmers were males $(79 \%)$ and the remaining were females $(21 \%)$ with varied education levels across adaptation strategies. Over $36.6 \%$ of the farmers had attended primary level, whereas $58.9 \%$ secondary level and $4.5 \%$ had attended tertiary level. Educational levels were significantly different $(=13.8, p=0.004, d f=4)$ between three adaptation choices. Post-hoc comparison after chi-square test indicated that the percentage of households switching crops and varieties was significantly different than households who change farming practice at $p<0.05$ probability level in terms of primary education. Farming experience of household head was ranged between 21-30 (35.4\%), 31-40 (53.3\%), 41-50 (9.4\%) and 51-60 (2.1\%) years. Most (78.7\%) households who change crops and varieties had access to information on local weather change through radio and/or television, followed by households diversifying livelihood options (58.6\%) and changing farm practices (49.3\%). The percentage of farmers who had reported access to weather information through radio and/or television are significantly different $(=5.22, p=0.032, d f=2)$ across the study districts. 
Table 2

Farmers' demographic and socio-economic features across the study districts.

\begin{tabular}{|c|c|c|c|c|c|c|c|}
\hline \multicolumn{2}{|c|}{ Household characteristics } & \multicolumn{5}{|c|}{$\%$ respondents } & \multirow{2}{*}{$\begin{array}{l}\chi^{2} \\
\text { value }\end{array}$} \\
\hline & & Total & $\begin{array}{l}\text { Change } \\
\text { in crop } \\
\text { and } \\
\text { variety }\end{array}$ & $\begin{array}{l}\text { Changing } \\
\text { farming } \\
\text { system }\end{array}$ & $\begin{array}{l}\text { Livelihood } \\
\text { diversification }\end{array}$ & $\begin{array}{l}\text { No } \\
\text { adaptation }\end{array}$ & \\
\hline \multicolumn{8}{|l|}{ Demographic } \\
\hline \multirow{2}{*}{$\begin{array}{l}\text { Household } \\
\text { head gender }\end{array}$} & Male & 79 & 74.1 & 78.3 & 81.6 & 76.2 & 0.59 \\
\hline & Female & 21 & 25.9 & 21.7 & 18.4 & 23.8 & \\
\hline \multirow{3}{*}{$\begin{array}{l}\text { Education } \\
\text { level }\end{array}$} & Primary & 36.6 & $48.4 a$ & $28.9 b$ & $37.9 a b$ & 55.3 & $13.8^{* *}$ \\
\hline & Secondary & 58.9 & $49.5 a$ & $60.0 a$ & $58.6 a$ & 32.7 & \\
\hline & Tertiary & 4.5 & $2.1 \mathrm{a}$ & $11.1 \mathrm{a}$ & $3.4 a$ & 12.0 & \\
\hline \multicolumn{8}{|l|}{$\begin{array}{l}\text { Socio- } \\
\text { economic }\end{array}$} \\
\hline \multirow{4}{*}{$\begin{array}{l}\text { Farming } \\
\text { experience } \\
\text { (in years) }\end{array}$} & $20-30$ & 35.4 & 33.2 & 36.7 & 36.0 & 26.4 & 1.46 \\
\hline & $31-40$ & 53.3 & 49.7 & 50.3 & 52.7 & 35.0 & \\
\hline & $41-50$ & 9.4 & 11.1 & 8.9 & 8.8 & 5.6 & \\
\hline & $51-60$ & 2.1 & 5.7 & 4.1 & 3.1 & 4.7 & \\
\hline \multirow{2}{*}{$\begin{array}{l}\text { Households } \\
\text { above } \\
\text { average land } \\
\text { size (in ha) }\end{array}$} & Yes & 54.8 & 50.4 & 61.3 & 50.2 & 53.7 & 2.75 \\
\hline & No & 44.2 & 9.55 & 8.37 & 49.8 & 46.3 & \\
\hline \multirow{2}{*}{$\begin{array}{l}\text { Households } \\
\text { having } \\
\text { TV/radio }\end{array}$} & Yes & 58.0 & $78.7 a$ & $67.8 \mathrm{~b}$ & $49.7 a b$ & 45.4 & $5.22^{\star \star}$ \\
\hline & No & 42 & 21.3 & 32.2 & 50.3 & 54.6 & \\
\hline
\end{tabular}

Data were obtained through household survey 2019. $\chi 2$ is chi-square value for test of associations. ** statistically significant at $5 \%$ probability level. $\mathrm{df}$ is degree of freedom. Percentage values with same letter in the same row are not statistically different at $(p<0.05)$ probability level. $n$ is the sample size.

\subsection{Farmers' adaptation strategies}

\section{Crop and variety selection}


More than half of the farmers switch to crops and variety adapting to fluctuations in a seasonal rainfall as their priority. About $57.9 \%$ switch cropping calendar, $30 \%$ select improved variety and $5 \%$ diversify cropping to deal with climate change risks (Table 3 ). Such modulation is occurred by shifting crop sowing date from mid-March to late April or early May. Farmers who perceive a decline in soil moisture due to increased evaporation modulate sowing date to distribute risks whilst ensuring that any rain was utilized to the maximum by the crops planted. This result is in line with findings in Uganda by Hisali et al. (2011) who showed that farmers who perceived increases in seasonal rainfall variability patterns, are likely to adjust sowing dates as an adaptation strategy.

To deal with adverse climate change risks, households also adopt both late- and early-maturing crop varieties to reduce adverse climate change effects (Table 3). Most of these farmers use both openpollinated and hybrid crop varieties that provide higher yields whilst coping with extreme climate events. Farmers reported that the use of such crop varieties does not only increase household income and reduce poverty, but also help them to deal with erratic rainfall patterns, frequent dry spells and sporadic droughts. This shows that the use of improved crop varieties is one of the farmers' adaptation strategies to climate change in the study area. This result supports the findings in Tanzania by Below et al. (2012) who reported that the use of drought-resistant crop varieties is one of the successful adaptation strategies to climate change. Moreover, farmers adopt drought-resistant root crops such as enset and cassava (Manihot esculenta) that provide large volume of food per unit area to reduce adverse climate change risks. As result, the use of such crops to deal with seasonal rainfall fluctuation, frequent droughts and prevalent diseases is identified as adaptation strategies in the study area. These results are consistent with findings in north central Ethiopia (Kassie et al. 2013; Adimassu et al. 2014) who showed the use of drought-resistant crop types is one of the farmers' adaptation strategies to climate change. 
Table 3

Farmers' climate change adaptation strategies across three study districts.

\begin{tabular}{|lll|}
\hline Adaptation strategies & & \% of respondents \\
\hline crop and variety selection $\mathrm{t}$ & Change croping date & 57.8 \\
\cline { 2 - 3 } & Swich crop varities & 30.0 \\
\cline { 2 - 3 } & Crop diversification & 5.0 \\
\cline { 2 - 3 } Shift in farming practice & Either of the combinations & 8.5 \\
\cline { 2 - 3 } & Harvest rainwater & 44.9 \\
\cline { 2 - 3 } Livelihood diversification & Integrate crops with trees & 49.8 \\
\cline { 2 - 3 } & Both strategies & 10.4 \\
\cline { 2 - 3 } & Diversify off-farm income & 56.6 \\
\cline { 2 - 3 } & Migrate for seasonal work & 15.7 \\
\cline { 2 - 3 } & Both strategies & 29.5 \\
\hline Do nothing & Do nothing to respond & 8.9 \\
\hline Data were obtained through household survey 2018. \\
\hline
\end{tabular}

Only $5 \%$ of the farmers had shifted from a sole maize production to mixed maize-legume productions to cope with drought stress (Table 3). Crop production by combining maize with legumes, notably pigeon peas (Cajanus cajan L.) and common beans (Pisum sativum L.) were used to maintain soil fertility and prevent nutrient losses. Although the incidence of crop pests and diseases is uncertain under climate change (Cairns et al. 2013), farmers reported that increased crop diversity across space and time could potentially help to improve yields. At the same time, farmers described that multiple planting over the same plot allows them to gain more yields from specific crops when other crops fail due to adverse climate change effects. This shows that cropping systems with large diversity are more stable as they can withstand changing conditions more than a single cropping system. These findings are consistent with results in Senegal by Mertz et al. (2009), in Nigerian Savannah Tambo and Abdoulaye (2013) and in Ethiopia by Adimassu et al. (2014) who revealed that crop diversification is one of preferred climate change adaptation strategies in SSA.

\section{Shift in farm practices}

About $49.8 \%$ of farmers integrate garden plants such as mango (Mangifera indica) and avocado (Persea americana) with maize to deal with soil degradation due to frequent run-off and floods (Table 3). Across adaptation practices, $44.9 \%$ of farmers harvest rainwater and $20 \%$ both agroforestry practices and rainwater harvesting practices. According to farmers, such practices have both economic and environmental benefits since they help to increase productivity by reducing organic matter loss. Farmers prune roots of these plants to reduce their competitions with crops. Other farmers plant perennial trees 
such as Eucalyptus regnans and Cordia africana to reduce the effects of soil degradation in highly rugged areas. Such tree species also help farmers by providing additional income from timbers. Likewise, farmers in Malawi plant Faidherbia albida that increases productivity and income by providing organic nitrogen for the soil and shades for crops (Sutcliffe et al. 2016). Although much experience is required to combine crops together with tree species on the same plot (Pramova et al. 2012), agroforestry practices further provide honey and traditional medicine (Brown et al. 2011), control pest and disease incidents (Hoang et al. 2014), and supply animal fodder (Shikuku et al. 2017).

Nearly half farmers use rainwater harvesting practices by installing contour ditches that retain water flowing down hills and micro-dams that supply irrigation water (Table 3). Farmers irrigate their farms by diverting nearby rivers and harvesting rainwater by installing ponds during the rainy seasons. Such practices do not only help to deal with erratic seasonal rainfall patterns and drought stress, but also influence use of improved crop varieties and fertilizers by increasing net returns. This finding is consistent with results in South Africa (Wilk et al. 2013) and in Zambia (Mulenga et al. 2016) who identified rainwater harvesting practices as adaptation strategies to climate change.

\section{Livelihood diversification}

About $56.7 \%$ of farmers implement livelihood diversification activities such as crafting, petty trading and carpentry as main off-farm income sources (Table 3 ). Almost $15.7 \%$ of farmers migrate to nearby cities in dry season in search of labour work. About $29.5 \%$ of farmers diversify their livelihood into non-farm income and migrate to nearby areas in search of daily jobs. Such sources help farmers to increase household income and build resilience by strengthening their capacity to adopt improved crop varieties and utilize irrigation that increase agricultural productivity. In line with this result, Adimassu et al. (2014) in north central Ethiopia revealed that the use of off-farm income diversification is one of the farmers' adaptation strategies to climate change. Diversification of livelihoods into off-farm income sources may provide farmers with a self-insurance to cope with climate change risks (Erenstein et al. 2011; Falco et al. 2011; Simelton et al. 2011; Cairns et al. 2013).

Almost half of farmers reported that they look to migrate (for 1-2 months) to nearby urban areas in search of labour work, especially during the dry seasons. Some household look to migrate (for 3-5 months) outside their communities for work on the large-scale sugarcane and flower farms that demand substantial number of labourers. Such migration helps farmers to build their livelihood resilience by providing additional household income that in turn strengthens their capacity to reinvest in the use of drought-resistant maize seeds. Consistent with our findings, results in northeast Ethiopia (Morrissey 2008), Tanzania (Below et al. 2012) and in Benin (Yegbemey et al. 2013) identified seasonal migration as one of the adaptation strategies to increase household income that reduce dependence on rainfed agriculture.

\subsection{Econometric model results}


Results show that farmers' choice of adaptation strategies is significantly influenced by several sociocognitive, behavioural, socio-economic and institutional factors such as access to weather information, land size, perceptions of climate change and farm experience. This is supported by the results of multinomial logistic regression model $(, p<0.05)$, suggesting its strong explanatory power (Table 4$)$.

Findings show that farmers' who have access to weather information through frequent extension contact at least two three times per week are likely to undertake new crops and varieties that can adapt changing climate. Access to accurate information through extension agents on weather forecast enhances farmers' adaptation choices by enabling them to make informed decisions and take advantage of favourable climate conditions. This relationship is also found positive and significant in terms of farmers' perception of increased seasonal rainfall variability. Perception of climate change risk is a mental construct by which stimuli is received from the climate hazards and combined into past experience obtained through social networks and mass media (Grothmann and Patt 2005). Responding to climate change requires three basic steps: (i) noticing changes in one's external environment; (ii) evaluating whether such changes need shifts in behaviour; and (iii) undertaking adaptation decisions and actions (Falco et al. 2011). For example, Nhemachena et al. (2014) revealed that farmers must first find evidence of climate change risks, and then make choices to identify useful strategies and subsequently implement these strategies to deal with risks. Farmers' perceptions of climate change is a precondition for their choice on what crops to produce and where (Simelton et al. 2013)

Results show that farmers who have small land size are highly likely to adjust farming practices within the context of climate change than actually they do. This is partly due to the fact that decrease in land size could increases farmers' potential to further use soil and water conservation practices, use rainwater harvesting practices and adopt chemical fertilizers that increase net agricultural productivity. The latter may be unavailable in desirable quantities or too costly for farmers who have large landholding. Another explanation is that large farms require high levels of labour and financial investments in using adaption strategies to climate change. For this reason, farmers with a large landholding might have lower capacity to invest in novel agricultural inputs such as improved crop varieties and fertilizers compared to farmers with a small landholding. The effect of land size on crop and varietal selection is found negative and significant. This shows that not only the size of the land, but also other farm and household characteristics that influence adaptation decision processes. This result is in line with findings in Nigeria by Nguezet et al. (2013) who revealed a negative relationship between farm size and the probability of adaptation choices.

Farmers who reported increases in drought risks are more likely to switch improved crops and variety and diversify their livelihoods into non-farm activities as well migrate to nearby cities in search of jobs. This might be because increase in temperatures will contribute to rising atmospheric water demand by leading to more erratic rainfall patterns and subsequently could influence farmers' potential adaptation adoption. Another explanation might be that increase in temperatures could significantly reduce soil moisture and hence it would influence farmers' decision to use improved, drought-resistant crop varieties. The relationship between farmers' perception of increased risks of erratic rainfall and shift in farm practices is 
found positive and significant. This result agrees with the findings in Malawi by Grabowski et al. (2019) who revealed positive and significant relationships between farmers' risk perceptions and adaptation choices.

Also, the probability of adaptation to shift farming practices by using rainwater harvesting and agroforestry practices and significantly increased amongst farmers who reported increased seasonal rainfall variability. This could be because lack of rainfall could adversely affect crop germination, growth and maturity; and this in turn would influence their choices to adjust sowing calendar. This shows that farmers' likely adaptation choice is significantly explained by their perceptions of increased seasonal rainfall variability during the sowing period. This relationship was positive and significant in terms of choice of improved crops and variety. This result supports findings of a study in Malawi by Simelton et al. (2011) who showed a significant association between farmers' perceptions of erratic seasonal rainfall variability and adoption of adaptation strategies.

Farmers' concerns regarding climate change occurrence and risks significantly influence their choice of crop varietal use and shift in farming practices. Although such effects are not compared with actual data, farmers' views regarding adverse climate change risks are consistent with findings in Ethiopia by Kassie et al. (2015). Local people's climate change beliefs describe their long-term experiences with past events (Abegunde 2017) and decisions to deal with future uncertainty (Hyland et al. 2015). Alam et al. (2017) revealed that farmers' experiences of climate change may be influenced by what they hear about these risks in the media, from friends, family and/or public agencies. Access to information on climate change is useful proxies to local people's beliefs in climate change. This implies that information delivered through extension agents on climate change should align with perspectives of local people by complementing their concerns linked to such impact. This is why Helgeson et al. (2012) contended that understanding people's beliefs towards climate change is a process of social interaction where local knowledge can be combined together with scientific thoughts. So, the argument that local knowledge can corroborate the scientific information on climate change has gained ground in recent years (Grothmann and Patt 2005; Singh and Nair 2014; Sutcliffe et al. 2016; Woods et al. 2017). 
Table 4

Multinomial logistic model results for explanatory variables predicting crop producers' adaptation choices $(n=340)$.

\begin{tabular}{|c|c|c|c|c|c|c|}
\hline \multirow[t]{2}{*}{ Explanatory variables } & \multicolumn{2}{|c|}{ Crop and variety } & \multicolumn{2}{|c|}{$\begin{array}{l}\text { Shift in farm } \\
\text { practice }\end{array}$} & \multicolumn{2}{|c|}{$\begin{array}{l}\text { Livelihood } \\
\text { diversification }\end{array}$} \\
\hline & Coef. & $\begin{array}{l}\text { Std } \\
\text { err }\end{array}$ & Coef. & Std err & Coef. & Std err \\
\hline Access to input price information & 0.276 & 1.289 & 1.836 & 0.560 & 0.274 & 1.79 \\
\hline Access to micro credit services & 0.155 & 0.254 & $3.002 * *$ & .907 & 0.394 & 0.265 \\
\hline Access to training on adaptation & 0.681 & 0.635 & 0.591 & 0.622 & 0.687 & 0.572 \\
\hline Access to weather information & $4.557^{\star \star}$ & 3.285 & $4.23^{\star \star}$ & 0.613 & 1.08 & 0.579 \\
\hline Access to extension contact & $2.340 \star \star$ & 1.098 & 0.453 & 0.234 & $2.349 * *$ & 1.290 \\
\hline $\begin{array}{l}\text { Belief on climate change occurrence } \\
\text { risks }\end{array}$ & $2.342^{\star \star}$ & 0.520 & 0.954 & 0.541 & 0.567 & 0.247 \\
\hline Education levels (in years) & 0.281 & 0.163 & 1.587 & 0.179 & 0.471 & 0.179 \\
\hline Extreme climate information access & $2.764^{\star \star}$ & 0.854 & 1.484 & 1.246 & $7.870 * \star$ & 1.623 \\
\hline Farming experience (in years) & $1.741^{\star}$ & 0.994 & 1.512 & 0.192 & 1.312 & 0.067 \\
\hline Gender of the household head & $3.780 \star \star$ & 0.449 & $1.847^{\star}$ & 0.303 & 1.389 & 0.425 \\
\hline Household non-farm income & 0.159 & 0.743 & 0.441 & 0.801 & 0.812 & 0.934 \\
\hline Household on-farm income & 0.226 & 0.564 & 0.254 & 0.502 & 0.653 & 0.367 \\
\hline $\begin{array}{l}\text { Perception of increased rainfall } \\
\text { intensity }\end{array}$ & $3.872 \star \star$ & 0.937 & .902 & 0.785 & $3.470 * *$ & 0.759 \\
\hline $\begin{array}{l}\text { Perception of increased erratic } \\
\text { rainfall }\end{array}$ & $2.843^{\star \star}$ & 2.091 & 1.889 & 0.031 & $1.595^{\star}$ & 0.860 \\
\hline $\begin{array}{l}\text { Perception of increased drought } \\
\text { risks }\end{array}$ & $3.871^{\star \star}$ & 2.701 & 1.967 & 0.771 & $3.642^{* \star}$ & 2.911 \\
\hline Size of the farm (in ha) & $-1.314^{\star}$ & 0.985 & $-.995^{\star}$ & 2.299 & 0.449 & 1.044 \\
\hline \multicolumn{7}{|l|}{ Model Summary } \\
\hline Chi-square & 0.632 & & & & & \\
\hline -2loglikelihood & 129.8 & & & & & \\
\hline Prob>F & 0.006 & & & & & \\
\hline
\end{tabular}

Base category: No adaptation. Std err is a standard error of the estimate. ${ }^{\star \star},{ }^{*}$ indicate significant at less than 5 and $10 \%$ probability level, respectively. 


\section{Conclusions}

The study findings revealed that climate change has a negative effect on smallholder crop producers' livelihoods. Such adverse climate change effects may result in a greater incidence of crop pests, loss of soil moisture content, rapid soil nutrient depletion and substantial decreases in crop productivity and yields. These effects in combination with lack of access to improved, high-yielding crop varieties, limited agricultural extension services and poor access to irrigation infrastructure could further threaten access to food, limit export earnings and markedly lower net crop revenue. As the adverse climate change effect is pronounced and farmers' capacity to adapt to such an impact becomes weak, a focus on understanding adaptation process should increase substantially. Despite diverse strategies employed to fight against climate risks, the smallholder farmers still remained vulnerable to poverty and food insecurity because their livelihoods are dependent of rainfed agriculture. This situation indicates the sensitivity of smallholder farmers to climate change and variability as agriculture is their main source of income. Different gender among the smallholder farmers employed different adaptation strategies such as crop variety and diversification, mixed cropping which was mainly adopted by male famers and changing planting dates employed mainly by female farmers as a way of mitigating the climatic risks. Explanatory variables that were significant in influencing choice of smallholder farmers when adapting to climate change were, access to extension contact, gender of the household, access to weather information, belief on climate change occurrence and risk perceptions of the households who are unfortunately lacking climate change knowledge and are supposed to provide support systems and interventions. Therefore, the local governments, non-governmental organizations, international donors, research and academic institutions needs to ensure that the identified adaptation strategies are promoted and supported to help mitigate the climatic risks, and the interaction between smallholder farmers and frontline extension officers delivering timely climate and seasonal weather information should be strengthened. There is also a need to train extension officers on climate change and adaptation strategies, as well as other conservation agricultural practices so they could also disseminate correct and accurate information to the farmers, for better adaptation and improve well-being of farmers.

\section{Declarations}

\section{Availability of data and materials}

Not applicable

\section{Competing interests}

The author declares that there are no competing interests.

\section{Funding}

Not applicable

\section{Authors' contributions}


The author read and approved the final manuscript

\section{Consent for publication}

Accept

\section{Acknowledgements:}

We strongly acknowledge local enumerators who provided support during data collection.

\section{References}

1. Abate, Tsedeke, Bekele Shiferaw, Abebe Menkir, Dagne Wegary, Yilma Kebede, Kindie Tesfaye, Menale Kassie, Gezahegn Bogale, Berhanu Tadesse, and Tolera Keno. 2015. "Factors That Transformed Maize Productivity in Ethiopia." Food Security 7 (5): 965-81. https://doi.org/10.1007/s12571-0150488-z.

2. Abegunde, Albert Ayorinde. 2017. "Local Communities' Belief in Climate Change in a Rural Region of Sub-Saharan Africa." Environment, Development and Sustainability 19 (4): 1489-1522. https://doi.org/10.1007/s10668-016-9816-5.

3. Adger, W. Neil. 2006. "Vulnerability." Global Environmental Change 16 (3): 268-81. https://doi.org/10.1016/j.gloenvcha.2006.02.006.

4. Adimassu, Zenebe, Aad Kessler, and Leo Stroosnijder. 2014. "Farmers' Strategies to Perceived Trends of Rainfall and Crop Productivity in the Central Rift Valley of Ethiopia." Environmental Development 11: 123-40. https://doi.org/10.1016/j.envdev.2014.04.004.

5. AGRA. 2014. African Agriculture Status Report: Climate Chnage and Smallholder Agriculture in SubSaharan Africa. Aliance for a Green Revolution in Africa (AGRA). Nirobi, Kenya. https://ccafs.cgiar.org.

6. Alam, G. M.Monirul, Khorshed Alam, and Shahbaz Mushtaq. 2017. "Climate Change Perceptions and Local Adaptation Strategies of Hazard-Prone Rural Households in Bangladesh." Climate Risk Management 17: 52-63. https://doi.org/10.1016/j.crm.2017.06.006.

7. Antwi-Agyei, Philip, Claire Helen Quinn, Samuel Godfried Kwasi Adiku, Samuel Nii Ardey Codjoe, Andrew John Dougill, Richard Lamboll, and Delali Benjamin Komla Dovie. 2016. "Perceived Stressors of Climate Vulnerability across Scales in the Savannah Zone of Ghana: A Participatory Approach." Regional Environmental Change, 1-15. https://doi.org/10.1007/s10113-016-0993-4.

8. Asfaw, Solomon, Nancy Mccarty, Leslie Lipper, and Aslihan Arslan. 2013. "144- Adaptation to Climate Change and Food Security:" In 4th International Conference of the African Asssociation of Agricultural Economics. Hammamet Tunisia.

9. Bandura, Albert. 2001. "Socio-Congtive Theory: An Agentic Perspective." Ann. Rev. Pschol. 52: 1-26. www. arjournals.annualreviews.org. 
10. Baudoin, M. 2014. “Enhancing Climate Change Adaptation in Africa Assessing the Role of Local Institutions in Southern Benin." Climate and Development 6 (2): 37-41. https://doi.org/10.1080/17565529.2013.844677.

11. Bedeke, Sisay Belay, and Fekadu Beyene. 2013. "Small-Scale Irrigation and Household Income Linkage: Evidence from Deder District, Ethiopia." African Journal of Agricultural Research 8 (34): 4441-51. https://doi.org/10.5897/AJAR12.1793.

12. Bedeke, Sisay, Wouter Vanhove, Muluken Gezahegn, Kolandavel Natarajan, and Patrick Van Damme. 2019. "Adoption of Climate Change Adaptation Strategies by Maize-Dependent Smallholders in Ethiopia." NJAS - Wageningen Journal of Life Sciences 88 (October 2018): 96-104. https://doi.org/10.1016/j.njas.2018.09.001.

13. Below, Till B., Khamaldin D. Mutabazi, Dieter Kirschke, Christian Franke, Stefan Sieber, Rosemarie Siebert, and Karen Tscherning. 2012. "Can Farmers' Adaptation to Climate Change Be Explained by Socio-Economic Household-Level Variables?" Global Environmental Change 22 (1): 223-35. https://doi.org/10.1016/j.gloenvcha.2011.11.012.

14. Below, Till B., Julia C. Schmid, and Stefan Sieber. 2014. "Farmers' Knowledge and Perception of Climatic Risks and Options for Climate Change Adaptation: A Case Study from Two Tanzanian Villages." Regional Environmental Change 15 (7): 1169-80. https://doi.org/10.1007/s10113-0140620-1.

15. Beshah, Tesfaye. 2003. "Understanding Farmers: Explaining Soil and Water Conservation in Konso, Wolaita and Wello, Ethiopia. A PhD Thesis, Accepted by Wagening University and Research Cente, Wageningen, The Netherlands." Wageningen. http://www.dow.wau.nl/eswc/.

16. Boansi, David, Justice A Tambo, and Marc Müller. 2017. "Analysis of Farmers ' Adaptation to Weather Extremes in West African Sudan Savanna." Weather and Climate Extremes 16 (March): 1-13. https://doi.org/10.1016/j.wace.2017.03.001.

17. Brooks, Nick, W. Neil Adger, and P. Mick Kelly. 2005. "The Determinants of Vulnerability and Adaptive Capacity at the National Level and the Implications for Adaptation." Global Environmental Change 15 (2): 151-63. https://doi.org/10.1016/j.gloenvcha.2004.12.006.

18. Brown, Douglas R, and Paul Dettmann. 2011. “Poverty Alleviation and Environmental Restoration Using the Clean Development Mechanism: A Case Study from Humbo, Ethiopia," 322-33. https://doi.org/10.1007/s00267-010-9590-3.

19. Bryan, Elizabeth, Temesgen T. Deressa, Glwadys A. Gbetibouo, and Claudia Ringler. 2009. "Adaptation to Climate Change in Ethiopia and South Africa: Options and Constraints." Environmental Science and Policy 12 (4): 413-26. https://doi.org/10.1016/j.envsci.2008.11.002.

20. Cairns, Jill E., Jon Hellin, Kai Sonder, Jos?? Luis Araus, John F. MacRobert, Christian Thierfelder, and B. M. Prasanna. 2013. "Adapting Maize Production to Climate Change in Sub-Saharan Africa." Food Security 5 (3): 345-60. https://doi.org/10.1007/s12571-013-0256-x.

21. Campbell, Bruce M., Philip Thornton, Robert Zougmoré, Piet van Asten, and Leslie Lipper. 2014. "Sustainable Intensification: What Is Its Role in Climate Smart Agriculture?" Current Opinion in 
Environmental Sustainability 8: 39-43. https://doi.org/10.1016/j.cosust.2014.07.002.

22. Conway, Declan, and E. Lisa F Schipper. 2011. "Adaptation to Climate Change in Africa: Challenges and Opportunities Identified from Ethiopia." Global Environmental Change 21 (1): 227-37. https://doi.org/10.1016/j.gloenvcha.2010.07.013.

23. Crane, T. A., C. Roncoli, and G. Hoogenboom. 2011. "Adaptation to Climate Change and Climate Variability: The Importance of Understanding Agriculture as Performance." NJAS - Wageningen Journal of Life Sciences 57 (3-4): 179-85. https://doi.org/10.1016/j.njas.2010.11.002.

24. CSA. 2016. "Report on Area and Production of Major Crops. The Federal Democratic Republic of Ethiopia Central Statistical Agency." Statistical Bulletin. Vol. 584. Addis Ababa. http://www.csa.gov.et/.

25. Cutter, Susan L, Christopher T Emrich, Jennifer J Webb, and Daniel Morath. 2009. "Social Vulnerability to Climate the Literature Social Vulnerability to Climate Literature." Final Report to Oxfam. Southern Carolina. https://www.oxfamamerica.org/.

26. Deressa, Temesgen Tadesse, Rashid M. Hassan, Claudia Ringler, Tekie Alemu, and Mahmud Yesuf. 2009. "Determinants of Farmers' Choice of Adaptation Methods to Climate Change in the Nile Basin of Ethiopia." Global Environmental Change 19 (2): 248-55.

https://doi.org/10.1016/j.gloenvcha.2009.01.002.

27. Descheemaeker, Katrien, Simon J. Oosting, Sabine Homann-Kee Tui, Patricia Masikati, Gatien N. Falconnier, and Ken E. Giller. 2016. "Climate Change Adaptation and Mitigation in Smallholder CropLivestock Systems in Sub-Saharan Africa: A Call for Integrated Impact Assessments." Regional Environmental Change. https://doi.org/10.1007/s10113-016-0957-8.

28. "Determinants of African Farmers ' Strategies for Adapting to Climate Change: Multinomial Choice Analysis." 2016, no. January 2008.

29. Dontsop Nguezet, Paul Martin, Aliou Diagne, Olusegun Victor Okoruwa, Vivian Ojehomon, and Victor Manyong. 2013. "Estimating the Actual and Potential Adoption Rates and Determinants of NERICA Rice Varieties in Nigeria." Journal of Crop Improvement 27 (5): 561-85. https://doi.org/10.1080/15427528.2013.811709.

30. Elum, Zelda A., David M. Modise, and Ana Marr. 2017. "Farmer's Perception of Climate Change and Responsive Strategies in Three Selected Provinces of South Africa." Climate Risk Management 16: 246-57. https://doi.org/10.1016/j.crm.2016.11.001.

31. Erenstein, Olaf, Girma Tesfahun Kassie, and Wilfred Mwangi. 2011. "Comparative Analysis of Maize Based Livelihoods in Drought Prone Regions of Eastern Africa: Adaptation Lessons for Climate Change." In Increasing Agricultural Productivity \& Enhancing Food Security in Africa:, 1-13. http://addis2011.ifpri.info/files/2011/10/Paper_4C_Olaf-Ernestein.pdf.

32. Falco, Salvatore. 2014. "Adaptation to Climate Change in Sub-Saharan Agriculture: Assessing the Evidence and Rethinking the Drivers." European Review of Agricultural Economics 41 (3): 405-30. https://doi.org/10.1093/erae/jbu014. 
33. Falco, Salvatore, Marcella Veronesi, and Mahmud Yesuf. 2011. "Does Adaptation to Climate Change Provide Food Security? A Micro-Perspective from Ethiopia." American Journal of Agricultural Economics 93 (3): 825-42. https://doi.org/10.1093/ajae/aar006.

34. Feder, Gershon, Richard. Just, and David Silberman. 1981. "Adoption of Agricultural Innovations in Developing Countries: A Survey." Economic Development and Cultural Change 33 (2): 255. https://doi.org/10.1086/451461.

35. Fisher, Monica, Tsedeke Abate, Rodney W. Lunduka, Woinishet Asnake, Yoseph Alemayehu, and Ruth B. Madulu. 2015. "Drought Tolerant Maize for Farmer Adaptation to Drought in Sub-Saharan Africa: Determinants of Adoption in Eastern and Southern Africa." Climatic Change 133 (2): 283-99. https://doi.org/10.1007/s10584-015-1459-2.

36. Gbetibouo, Glwadys Aymone. 2009. "Understanding Farmers' Perceptions and Adaptations to Climate Change and Variability: The Case of the Limpopo Basin, South Africa." IFPRI Discussion Paper 00849, no. February: 52. https://doi.org/10.1068/a312017.

37. Gebrehiwot, Tagel, and Anne Van Der Veen. 2013. "Farm Level Adaptation to Climate Change: The Case of Farmer's in the Ethiopian Highlands." Environmental Management 52 (1): 29-44. https://doi.org/10.1007/s00267-013-0039-3.

38. Grabowski, Philip, Laura Schmitt Olabisi, Jelili Adebiyi, Kurt Waldman, Robert Richardson, Leonard Rusinamhodzi, and Sieglinde Snapp. 2019. "Assessing Adoption Potential in a Risky Environment: The Case of Perennial Pigeonpea." Agricultural Systems 171 (January): 89-99. https://doi.org/10.1016/j.agsy.2019.01.001.

39. Greene, WH William H. 2012. Econometric Analysis. Prentice Hall. Vol. 97. https://doi.org/10.1198/jasa.2002.s458.

40. Grothmann, Torsten, and Anthony Patt. 2005. "Adaptive Capacity and Human Cognition: The Process of Individual Adaptation to Climate Change." Global Environmental Change 15 (3): 199-213. https://doi.org/10.1016/j.gloenvcha.2005.01.002.

41. Helgeson, Jennifer, Sander Van Der Linden, and Ilan Chabay. 2012. "Learning for Sustainability in Times of Accelerating Change." In Aadaptation Process, 329-46. https://doi.org/10.3920/978-908686-757-8.

42. Hisali, Eria, Patrick Birungi, and Faisal Buyinza. 2011. "Adaptation to Climate Change in Uganda: Evidence from Micro Level Data." Global Environmental Change 21 (4): 1245-61. https://doi.org/10.1016/j.gloenvcha.2011.07.005.

43. Hoang, M.H. H, S. Namirembe, M. van Noordwijk, D. Catacutan, I. Öborn, a.S. S Perez-Teran, H.Q. Q Nguyen, and M.K. K Dumas-Johansen. 2014. "Farmer Portfolios, Strategic Diversity Management and Climate-Change Adaptation - Implications for Policy in Vietnam and Kenya." Climate and Development 6 (3): 216-25. https://doi.org/10.1080/17565529.2013.857588.

44. Hyland, John J., Davey L. Jones, Karen A. Parkhill, Andrew P. Barnes, and A. Prysor Williams. 2015. "Farmers' Perceptions of Climate Change: Identifying Types." Agriculture and Human Values, no. May. https://doi.org/10.1007/s10460-015-9608-9. 
45. IPCC. 2007. "Summary for Policymakers. In: Parry ML, Canziani OF, Palutikof J, van Der Linden P, Hanson C. (Eds.), Climate Change 2007: Impacts, Adaptation and Vulnerability. Contribution of Working Group II to the Fourth Assessment Report of the Intergovernmental Pan." Edited by C. (Eds.) In: Palutikof, J., van der Linden, P., Hanson. New York Cambridge University Press. https://doi.org/10.1038/446727a.

46. Kassie, Belay Tseganeh, Huib Hengsdijk, Reimund R??tter, Helena Kahiluoto, Senthold Asseng, and Martin Van Ittersum. 2013. "Adapting to Climate Variability and Change: Experiences from CerealBased Farming in the Central Rift and Kobo Valleys, Ethiopia." Environmental Management 52 (5): 1115-31. https://doi.org/10.1007/s00267-013-0145-2.

47. Kassie, Menale, Moti Jaleta, Bekele Shiferaw, Frank Mmbando, and Mulugetta Mekuria. 2013. "Adoption of Interrelated Sustainable Agricultural Practices in Smallholder Systems: Evidence from Rural Tanzania." Technological Forecasting \& Social Change 80 (3): 525-40. https://doi.org/10.1016/j.techfore.2012.08.007.

48. Kassie, Menale, Hailemariam Teklewold, and Moti Jaleta. 2015. "Understanding the Adoption of a Portfolio of Sustainable Intensification Practices in Eastern and Southern Africa." Land Use Policy 42: 400-411. https://doi.org/10.1016/j.landusepol.2014.08.016.

49. Kassie, Menale, Precious Zikhali, Kebede Manjur, and Sue Edwards. 2008. "Adoption of Organic Farming Technologies: Environment for Development Adoption of Organic Farming Techniques."

50. Kearney, Anne. 1994. "Understanding Global Change: A Cognitive Perspective on Communicating through Stories." Climatic Change, no. 6: 419-41. https://doi.org/10.1007/BF01096270.

51. Khan, A. \& Akhtar, S. 2015. Agricultural Adaptation and Climate Change Policy for Crop Production in Africa. Crop Production and Global Environmental Issues. Crop Production and Global Environmental Issues. https://doi.org/10.1007/978-3-319-23162-4.

52. Kotir, Julius H. 2011. Climate Change and Variability in Sub-Saharan Africa: A Review of Current and Future Trends and Impacts on Agriculture and Food Security. https://doi.org/10.1007/s10668-0109278-0.

53. Li, Sen, Linda Juhász-Horváth, Paula A. Harrison, László Pintér, and Mark D.A. Rounsevell. 2017. "Relating Farmer's Perceptions of Climate Change Risk to Adaptation Behaviour in Hungary." Journal of Environmental Management 185: 21-30. https://doi.org/10.1016/j.jenvman.2016.10.051.

54. Mertz, Ole, Cheikh Mbow, Anette Reenberg, and Awa Diouf. 2009. "Farmers' Perceptions of Climate Change and Agricultural Adaptation Strategies in Rural Sahel." Environmental Management 43 (5): 804-16. https://doi.org/10.1007/s00267-008-9197-0.

55. Mimura, N, R.S. Pulwarty, D.M. Duc, I. Elshinnawy, M.H. Redsteer, H.Q. Huang, J.N. Nkem, and R.a. Sanchez Rodriguez. 2014. "15. Adaptation Planning and Implementation." Assessment Report 5Climate Change 2014: Impacts, Adaptation, and Vulnerability. Part A: Global and Sectoral Aspects, 869-98. https://doi.org/10.1029/2003JD004173.Aires.

56. Morrissey, James W. 2008. Rural-urban migration in Ethiopia Forced Migration Review 28-29. 
57. Mudzonga, E. 2012. “Farmers ' Adaptation to Climate Change in Chivi District of Zimbabwe," 1-30. http://trapca.org/working-papers/Evengelista_adaptationtoclimatechangerevised.pdf.

58. Mulenga, Brian P, Ayala Wineman, and Nicholas J Sitko. 2016. "Climate Trends and Farmers' Perceptions of Climate Change in Zambia." Environmental Management, 0-1. https://doi.org/10.1007/s00267-016-0780-5.

59. Ndiritu, S. Wagura, Menale Kassie, and Bekele Shiferaw. 2014. "Are There Systematic Gender Differences in the Adoption of Sustainable Agricultural Intensification Practices? Evidence from Kenya." Food Policy 49 (P1): 117-27. https://doi.org/10.1016/j.foodpol.2014.06.010.

60. Neufeldt, Henry, Molly Jahn, Bruce M Campbell, John R Beddington, Fabrice Declerck, Alessandro De Pinto, Jay Gulledge, et al. 2013. "Beyond Climate-Smart Agriculture: Toward Safe Operating Spaces for Global Food Systems." Agriculture \& Food Security 2: 1-6.

61. Nhemachena, Charles, Rashid Hassan, and James Chakwizira. 2014. "Analysis of Determinants of Farm-Level Adaptation Measures to Climate Change in Southern Africa" 6 (5): 232-41. https://doi.org/10.5897/JDAE12.0441.

62. Nhemachena, Charles, and Rashid M Hassan. 2007. "Micro-Level Analysis of Farmers 'Adaptation to Climate Change in Southern Africa." 00714. NY, USA.

63. Niang, I., O.C. Ruppel, M.A. Abdrabo, A. Essel, C. Lennard, J. Padgham, and P. Urquhart. 2014. "Africa. In: Climate Change 2014: Impacts, Adaptation, and Vulnerability. Part B: Regional Aspects. Contribution of Working Group II to the Fifth Assessment Report of the Intergovernmental Panel on Climate Change [Barros, V.R., C.B. Field, D.J. Dokken, M.D."

64. Niles, Meredith T., Margaret Brown, and Robyn Dynes. 2016. "Farmer's Intended and Actual Adoption of Climate Change Mitigation and Adaptation Strategies." Climatic Change 135 (2): 277-95. https://doi.org/10.1007/s10584-015-1558-0.

65. Niles, Meredith T., and Nathaniel D. Mueller. 2016. "Farmer Perceptions of Climate Change: Associations with Observed Temperature and Precipitation Trends, Irrigation, and Climate Beliefs." Global Environmental Change 39: 133-42. https://doi.org/10.1016/j.gloenvcha.2016.05.002.

66. Oppenheimer, Michael, Maximiliano Campos, Rachel Warren, Joern Birkmann, George Luber, Brian O’Neill, and Kiyoshi Takahashi. 2014. "Emergent Risks and Key Vulnerabilities." Climate Change 2014: Impacts, Adaptation, and Vulnerability. Part A: Global and Sectoral Aspects. Contribution of Working Group II to the Fifth Assessment Report of the Intergovernmental Panel on Climate Change, 1039-99. https://doi.org/10.1017/CB09781107415379.

67. Piya, Luni, Keshav Lall Maharjan, and Niraj Prakash Joshi. 2013. "Determinants of Adaptation Practices to Climate Change by Chepang Households in the Rural Mid-Hills of Nepal." Regional Environmental Change 13 (2): 437-47. https://doi.org/10.1007/s10113-012-0359-5.

68. Pramova, Emilia, Bruno Locatelli, Houria Djoudi, and Olufunso A. Somorin. 2012. "Forests and Trees for Social Adaptation to Climate Variability and Change." Wiley Interdisciplinary Reviews: Climate Change 3 (6): 581-96. https://doi.org/10.1002/wcc.195. 
69. Reed, M. S., G. Podesta, I. Fazey, N. Geeson, R. Hessel, K. Hubacek, D. Letson, et al. 2013. “Combining Analytical Frameworks to Assess Livelihood Vulnerability to Climate Change and Analyse Adaptation Options." Ecological Economics 94: 66-77. https://doi.org/10.1016/j.ecolecon.2013.07.007.

70. Rogers, Everett M., Arvind Singhal, and Margaret M. Quinlan. 2019. “Diffusion of Innovations.” An Integrated Approach to Communication Theory and Research, Third Edition, no. December 2016 : 415-33. https://doi.org/10.4324/9780203710753-35.

71. Rogers, R.W. 1983. Cognitive and Physiological Processes in Fear Appeals and Attitude Change: A Revised Theory of Protection Motivation. In J. Cacioppo \& R. Petty (Eds.), Social Psychophysiology. Edited by Eds. In: Cacioppo, J. and Petty, R. Social Psychophysiology. New Yourk: Guilford Press.

72. Shi, Wenjiao, and Fulu Tao. 2014. "Vulnerability of African Maize Yield to Climate Change and Variability during 1961-2010.” Food Security 6 (4): 471-81. https://doi.org/10.1007/s12571-0140370-4.

73. Shiferaw, Bekele, Kindie Tesfaye, Menale Kassie, Tsedeke Abate, B M Prasanna, and Abebe Menkir. 2014. "Managing Vulnerability to Drought and Enhancing Livelihood Resilience in Sub-Saharan Africa: Technological, Institutional and Policy Options." Weather and Climate Extremes 3: 67-79. https://doi.org/10.1016/j.wace.2014.04.004.

74. Shikuku, Kelvin M, Roberto O Valdivia, Birthe K Paul, Caroline Mwongera, Leigh Winowiecki, Peter Läderach, Mario Herrero, and Silvia Silvestri. 2017. “Prioritizing Climate-Smart Livestock Technologies in Rural Tanzania: A Minimum Data Approach.” Agricultural Systems Journal 151: 204-16. https://doi.org/10.1016/j.agsy.2016.06.004.

75. Simelton, Elisabeth, Claire H. Quinn, Nnyaladzi Batisani, Andrew J. Dougill, Jen C. Dyer, Evan D.G. Fraser, David Mkwambisi, Susannah Sallu, and Lindsay C. Stringer. 2013. "Is Rainfall Really Changing? Farmers' Perceptions, Meteorological Data, and Policy Implications." Climate and Development 5 (2): 123-38. https:// doi.org/10.1080/17565529.2012.751893.

76. Simelton, Elisabeth, Claire H Quinn, Philip Antwi-, Nnyaladzi Batisani, Andrew J Dougill, Jen Dyer, Evan D G Fraser, et al. 2011. "African Farmers ' Perceptions of Erratic Rainfall October 2011 Centre for Climate Change Economics and Policy," no. 73: 1-36.

77. Smit, Barry, and Mark W Skinner. 2002. "Adaptation Option in Agriculture to Climate Chnage: A Typology." Mitigation and Adaptation Strategies for Global Change 7: 85-114.

78. Smit, Barry, and Johanna Wandel. 2006. "Adaptation, Adaptive Capacity and Vulnerability." Global Environmental Change 16 (3): 282-92. https://doi.org/10.1016/j.gloenvcha.2006.03.008.

79. Sutcliffe, Chloe, Andrew J. Dougill, and Claire H. Quinn. 2016. “Evidence and Perceptions of Rainfall Change in Malawi: Do Maize Cultivar Choices Enhance Climate Change Adaptation in Sub-Saharan Africa?" Regional Environmental Change 16 (4): 1215-24. https://doi.org/10.1007/s10113-0150842-x.

80. Tambo, Justice A. 2016. "International Journal of Disaster Risk Reduction Adaptation and Resilience to Climate Change and Variability in North-East Ghana." International Journal of Disaster Risk Reduction 17: 85-94. https://doi.org/10.1016/j.ijdrr.2016.04.005. 
81. Tambo, Justice Akpene, and Tahirou Abdoulaye. 2013. “Smallholder Farmers' Perceptions of and Adaptations to Climate Change in the Nigerian Savanna." Regional Environmental Change 13 (2): 375-88. https://doi.org/10.1007/s10113-012-0351-0.

82. Tesfahunegn, Gebreyesus Brhane, Kirubel Mekonen, and Abadi Tekle. 2016. "Farmers' Perception on Causes, Indicators and Determinants of Climate Change in Northern Ethiopia: Implication for Developing Adaptation Strategies." Applied Geography 73: 1-12. https://doi.org/10.1016/j.apgeog.2016.05.009.

83. Tessema, Yibekal A, Chanyalew S Aweke, and Getachew S Endris. 2013. "Understanding the Process of Adaptation to Climate Change by Small-Holder Farmers: The Case of East Hararghe Zone, Ethiopia," 1.

84. Thornton, K. \& Herrero, M. 2014. "Climate Change Adaptation in Mixed Crop-livestock Systems in Developing Countries." Nairobi, Kenya. https://doi.org/10.1002/jssc.201300750.This.

85. Tongruksawattana, Songporne. 2014. "Climate Shocks and Choice of Adaptation Strategy for Kenyan Maize-Legume Farmers: Insights from Poverty, Food Security and Gender Perspectives. Socioeconomics Program Working Paper." 11. Nairobi, Kenya.

86. Vignola, Raffaele, Celia Alice, Pavel Bautista-solis, Jacques Avelino, Bruno Rapidel, Camila Donatti, and Ruth Martinez. 2015. "Agriculture, Ecosystems and Environment Ecosystem-Based Adaptation for Smallholder Farmers : Definitions, Opportunities and Constraints." "Agriculture, Ecosystems and Environment"211: 126-32. https://doi.org/10.1016/j.agee.2015.05.013.

87. Wainaina, Priscilla, Songporne Tongruksawattana, and Matin Qaim. 2016. "Tradeoffs and Complementarities in the Adoption of Improved Seeds, Fertilizer, and Natural Resource Management Technologies in Kenya." Agricultural Economics (United Kingdom) 47 (3): 351-62. https://doi.org/10.1111/agec.12235.

88. Wilk, Julie, Lotta Andersson, and Michele Warburton. 2013. "Adaptation to Climate Change and Other Stressors among Commercial and Small-Scale South African Farmers," 273-86. https://doi.org/10.1007/s10113-012-0323-4.

89. Woods, Bryndís Arndal, Helle Ørsted Nielsen, Anders Branth Pedersen, and Dadi Kristofersson. 2017. "Farmers' Perceptions of Climate Change and Their Likely Responses in Danish Agriculture." Land Use Policy 65 (April): 109-20. https://doi.org/10.1016/j.landusepol.2017.04.007.

90. WZANRD. 2015. “Description about Wolaita Zone. Wolaita Zone Agriculture and Natural Resource Department Office, Wolaita Sodo, Ethiopia." Sodo. http://ethioagp.org/ministry-of-agriculture-moa/.

91. Yaro, Joseph Awetori. 2013. "The Perception of and Adaptation to Climate Variability / Change in Ghana by Small-Scale and Commercial Farmers," 1259-72. https://doi.org/10.1007/s10113-0130443-5.

92. Yegbemey, Rosaine N., Jacob A. Yabi, Silvère D. Tovignan, Geoffroy Gantoli, and Sènakpon E. Haroll Kokoye. 2013. "Farmers' Decisions to Adapt to Climate Change under Various Property Rights: A Case Study of Maize Farming in Northern Benin (West Africa)." Land Use Policy 34: 168-75. https://doi.org/10.1016/j.landusepol.2013.03.001. 
Figures

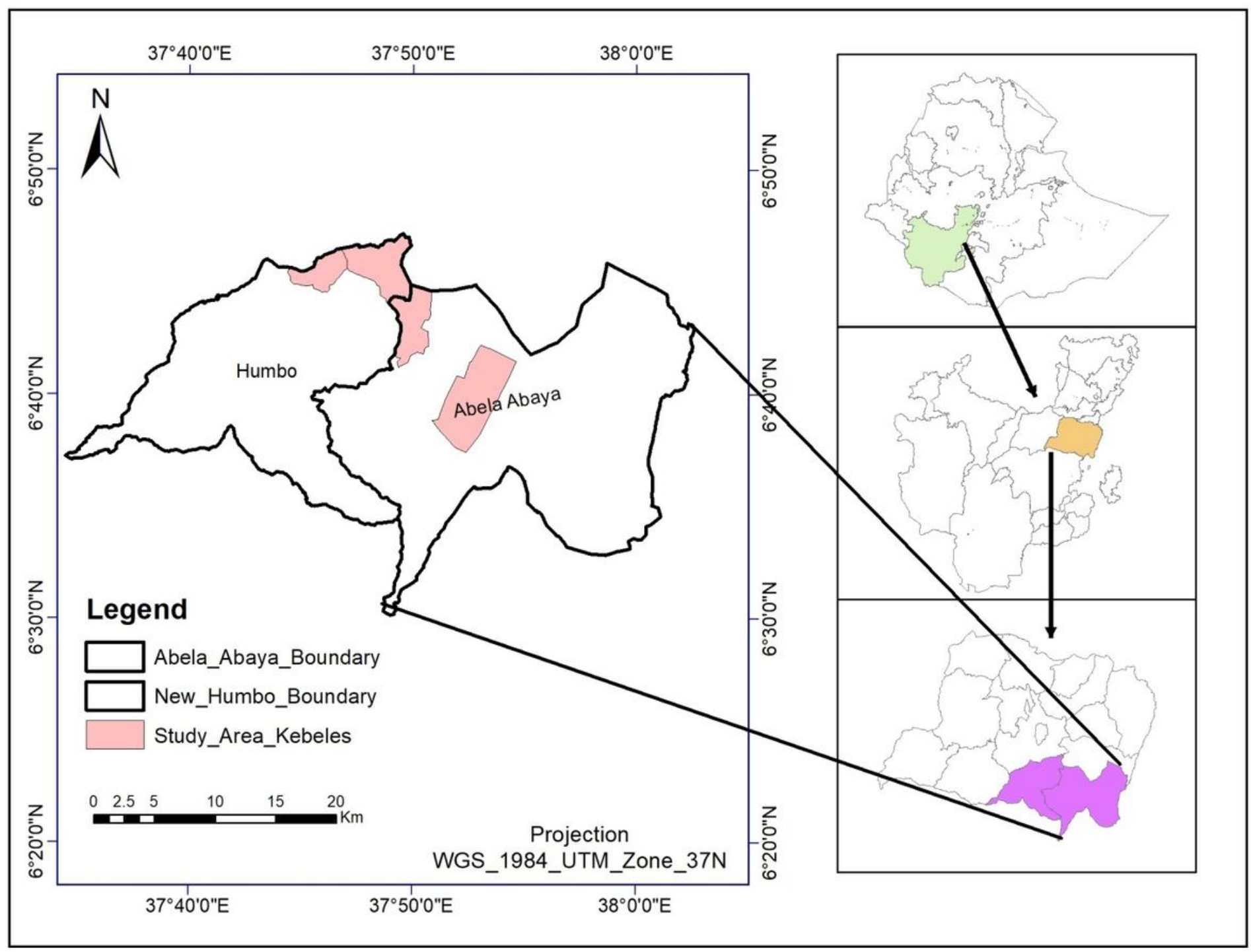

Figure 1

Map of the study site, Source: Ethio-GIS, 2019 